\title{
Human rabies in China: evidence-based suggestions for improved case detection and data gathering
}

Hao Li $i^{1}$, Jia-Jia Liư ${ }^{2}$, Shu-Jun Ding ${ }^{3}$, Liang Cai ${ }^{4}$, Yun Feng ${ }^{5}$, Peng-Cheng Y ${ }^{2}$, Shu-Qing Liư ${ }^{2}$ Xue-Xin Lư ${ }^{2}$, Xiao-Yan Tao ${ }^{2^{*}}$ id and Wu-Yang Zhu ${ }^{2}$

\begin{abstract}
Background: China still suffers heavily from rabies, although reported human cases continue to decrease year over year. There are far fewer laboratory-confirmed human cases than clinically diagnosed cases, which is a big problem that needs to be addressed. In this report, we summarize analyses of all specimens from human cases tested in our laboratory over the past 15 years, in order to promote laboratory diagnosis of rabies.

Methods: From 2005 to 2019, a total of 271 samples from 164 suspected rabies cases were collected from local hospitals by the local Centers for Disease Control and Prevention (CDCs) in China. Saliva, cerebrospinal fluid (CSF), serum (blood) and urine were collected for ante-mortem diagnosis, and brain tissue, neck skin tissue and cornea were collected for post-mortem diagnosis. All of the specimens were tested by reverse transcription-polymerase chain reaction (RT-PCR), and brain tissues were also tested using fluorescent antibody test (FAT). The number of positive test results obtained using different fluids or tissues, and at different stages of the disease, were compared using a chi-square test and a more effective sampling program is recommended.

Results: As the national reference laboratory for rabies surveillance in China, our laboratory has tested 271 samples from 164 suspected rabies cases collected by local CDCs since 2005. We found that saliva gave the highest number of positive test results (32\%), compared with CSF and other fluids. We also found that serum or blood specimens collected in the last 3 days of life can test positive by RT-PCR.

Conclusions: Serum or blood samples collected in the last 3 days of a patient's life can be used to measure viral RNA, which means that serum samples, as well as saliva and CSF, can be used to detect viral RNA for anti-mortem diagnosis of rabies. Because of our findings, we have modified our "National Surveillance Project for Human Rabies", by adding the collection and testing of serum samples from the end of the survival period. This will improve our national surveillance and laboratory diagnosis of human rabies.
\end{abstract}

Keywords: Rabies, Human case, Diagnosis, Specimen, Detection

\footnotetext{
* Correspondence: txy212@126.com

${ }^{2}$ National Health Commission of the People's Republic of China, Key Laboratory of Biosafety, National Institute for Viral Disease Control and Prevention, Chinese Center for Disease Control and Prevention, 155 Changbai Road, Changping District, Beijing 102206, China

Full list of author information is available at the end of the article
}

(C) The Author(s). 2020 Open Access This article is licensed under a Creative Commons Attribution 4.0 International License, which permits use, sharing, adaptation, distribution and reproduction in any medium or format, as long as you give appropriate credit to the original author(s) and the source, provide a link to the Creative Commons licence, and indicate if changes were made. The images or other third party material in this article are included in the article's Creative Commons licence, unless indicated otherwise in a credit line to the material. If material is not included in the article's Creative Commons licence and your intended use is not permitted by statutory regulation or exceeds the permitted use, you will need to obtain permission directly from the copyright holder. To view a copy of this licence, visit http://creativecommons.org/licenses/by/4.0/ The Creative Commons Public Domain Dedication waiver (http://creativecommons.org/publicdomain/zero/1.0/) applies to the data made available in this article, unless otherwise stated in a credit line to the data. 


\section{Background}

Rabies is a fatal infectious viral disease that claims an estimated 59000 human lives annually, mostly among underserved rural populations in Africa and Asia [1-3]. China is one of the countries affected by rabies and the number of human cases have fallen from 3300 in 2007 to 516 in 2017 under the government's efforts [4-7].

In 2018, the World Health Organization (WHO) and other international agencies launched a global strategic plan to end human deaths from dog mediated rabies by 2030 [8]. China is actively responding to this call and is trying to improve capacity for the surveillance and control of rabies. Rabies, which is caused by viruses of the genus Lyssavirus, presents as an acute, progressive encephalitis $[8,9]$. Clinical diagnosis of encephalitis can be difficult, and laboratory methods should be used to confirm a diagnosis whenever possible $[8,10]$. In China, the low number of laboratory-confirmed cases of human rabies is an urgent problem that is hampering the elimination of rabies.

The WHO Expert Consultation on Rabies recommends that secretions, biological fluids (such as saliva, cerebrospinal fluid [CSF] and serum) and some tissues (such as skin biopsy samples, including hair follicles at the nape of the neck) should be used to diagnose rabies during life. Brain tissue is the preferred specimen for post-mortem diagnosis [8]. In China, however, it is very difficult to collect a brain specimen, or even a skin biopsy sample. CSF and serum samples are recommended for the detection of antibodies to the virus. Tests for neutralizing antibodies, such as the rapid fluorescent focus inhibition test (RFFIT), are, however, complicated and thus difficult to carry out in the local Centers for Disease Control and Prevention (CDCs) in China. Detection of viral RNA in bodily fluids is, therefore, the most important method for diagnosis of human rabies in China. The analysis of multiple different samples (e.g., skin, saliva, urine) at different stages of the disease has been shown to improve detection rate and is recommended for in life diagnosis [11].

As the national reference laboratory for rabies surveillance in China, our laboratory is responsible for training staff from the laboratories of provincial CDCs, and we have analyzed specimens of suspected rabies cases, collected by local CDCs, since 2005. In this report, we summarize the analyses of all specimens from human cases carried out by our laboratory over the past 15 years, and compare the rate of positive results from samples of different fluids or tissues and from different stages of the disease. Based on our results, we recommend a more effective sampling program, which will be a useful guide for improving the number of confirmed human rabies cases in China and other countries in a similar position.

\section{Methods}

Ethics statement

All human clinical specimens included in this study were collected by local CDCs for diagnostic confirmation of rabies in clinically suspected cases. The specimens were collected under the guidance of physicians and with the permission of the patients' relatives. The specimens were then submitted to our laboratory for detection. All human samples were anonymized in this study. The program for collection of human specimens was approved by the Ethical Committee of the National Institute of Viral Disease Control and Prevention, China CDC.

\section{Specimens}

Between 2005 and 2019, a total of 271 samples from 164 suspected rabies cases were collected from hospitals by local CDCs. The specimens included saliva, CSF, serum (blood) and urine for ante-mortem diagnosis, together with brain tissue, neck skin tissue and corneas for postmortem diagnosis.

\section{Detections}

Brain tissue, neck skin and cornea specimens were tested for rabies using FAT as previously described [12, 13]. Except for one cornea specimen, all of the samples, including fluids (saliva, CSF, serum and urine) and brain and skin tissues, were tested for the presence of viral RNA by nested RT-PCR as described earlier [14, 15]. Testing of serum specimens for viral RNA is not, however, recommended [8] and the WHO suggest collecting serum samples only for the detection of virus neutralizing antibodies in unvaccinated patients, but these tests are not very sensitive. The tests for neutralizing antibodies, such as RFFIT, are, however, very specialized and are difficult to popularize in local laboratories.

\section{Statistical analysis}

Statistical analysis was carried out using SPSS version 25 (IBM Corp. Armonk, NY, USA), and a chi-square test was used to compare the positive test rate among the different types of samples (Table 1). The data will help us to decide whether sampling a particular fluid or tissue gives a higher positive detection rate and will thus be a better choice for diagnosis.

\section{Results}

\section{Distribution of samples}

In total, 271 samples were collected over the past 15 years (Fig. 1). Only one sample was collected in 2005, with a slight increase in samples in 2006 , followed by reduced sample numbers from 2007 to 2009. The largest numbers of samples were collected between 2010 and 2012, with relatively low and stable numbers over the last eight years. A total of 16 provinces submitted 
Table 1 The detection results of different type samples

\begin{tabular}{lllll}
\hline & Samples & $\begin{array}{l}\text { Total } \\
\text { numbers }\end{array}$ & Positive numbers & Positive rate (\%) \\
\hline Anti-mortem & Saliva & 125 & 40 & 32.0 \\
& Urine & 14 & 0 & 0.0 \\
& Cerebrospinal fluid & 19 & 4 & 21.1 \\
& Serum (Blood) & 85 & 9 & 10.6 \\
Post-mortem & Brain tissue & 23 & 23 & 100.0 \\
& Neck skin tissue & 4 & 0 & 50.0 \\
& Cornea tissue & 1 & & 0.0 \\
\hline
\end{tabular}

specimens, either continually or intermittently (Fig. 1). The largest numbers of samples were collected in 2011 (from eight provinces) and in 2012 (from six provinces). In other years, samples were obtained from 1 to 4 provinces.

Most samples were collected in Shandong, Hunan, Beijing and Yunnan, with about ten specimens from Tibet, Xinjiang, Gansu, Zhejiang and Liaoning. Six samples were collected in Qinghai, and only 1-3 samples were submitted from Guizhou, Shanxi, Shanghai, Guangxi, Anhui and Sichuan.

\section{Analysis of specimens}

All samples were analyzed using the nested RT-PCR method for detection of viral RNA. Brain and skin tissues, together with one cornea sample, were also analyzed using FAT method. The cornea sample was too firm to process for RNA analysis and was only detected using FAT. The results from all samples are summarized in Table 1.

For anti-mortem diagnosis, saliva samples gave the highest positive rate (32\%), followed by CSF samples (around 21\%). All 14 urine samples tested negative. Most notably, 9/85 (10\%) serum (or blood) samples tested positive for viral RNA. Our results thus provide a new supplementary method to the recommended sampling procedure for suspected cases of rabies.

In the post-mortem diagnoses, the brain samples from all 23 cases tested positive. Neck skin tissues were available for two of the cases and these also tested positive. Only one cornea sample was available and this tested negative, despite a positive result from the brain sample.

The chi-square test showed that there was a significant different between positive test rates for different types of anti-mortem specimen $(P<0.001)$. Pairwise comparisons also showed a significant different between saliva and urine tests $(P=0.01)$ and between saliva and serum tests $(P<0.001)$.

\section{Laboratory-confirmed cases}

A total of 65 of the 164 clinically suspected cases had a laboratory-confirmed diagnosis. Only one specimen was available for 114 suspected cases and two or more specimens were available for 50 suspected cases. Of the confirmed cases, 41 had only one available specimen and 24 had two or more available specimens. Of the 40 cases

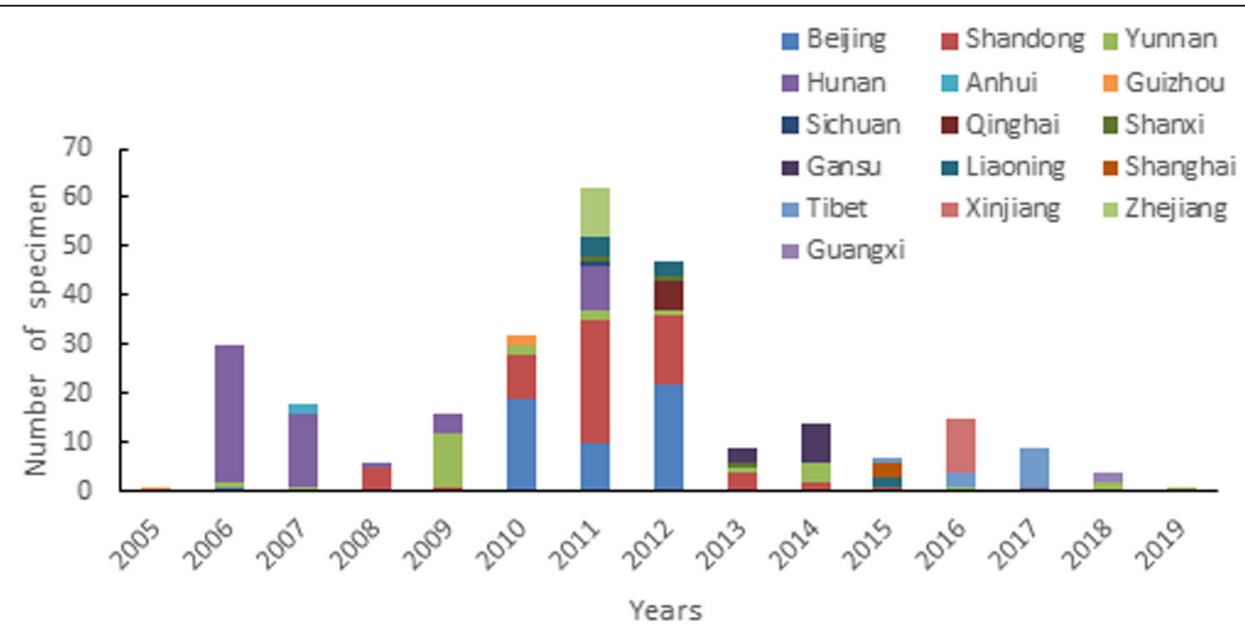

Fig. 1 Numbers of specimens collected annually from different provinces 
that had a positive anti-mortem diagnosis, 25 were confirmed by post-mortem diagnosis.

\section{Effect of sampling time}

Data for 18 cases (with 40 samples) confirmed by antimortem diagnosis, with complete or partial clinical information, are listed in Table 2. It's clear that saliva samples were tested earlier and more easily than CSF samples. Saliva samples from Case 1 and 7, collected on day 2 (post-onset of symptoms), tested positive. Only two CSF samples (Case 3 and Case 7) tested positive and, in each case, the saliva sample also tested positive. Case 4 and 10 showed the typical characteristics of intermittent shedding in saliva samples.

\section{Positive serum samples for viral RNA detection}

Although the WHO only recommends collection of serum for viral antibody tests, we found that 10.6\% (9/ 85) serum samples tested positive using RT-PCR (Tables 1 and 2). Seven cases were confirmed using only serum samples, another two cases were confirmed using both serum and saliva samples (Case 4 and Case 5). In the final days of life, serum samples were very sensitive and always tested positive during $0-3$ days before death (Case 10, 12, 15 and 18). In Case 9, each serum sample collected in the last 3 days before death tested positive for viral RNA. Serum samples from the late stage of disease in four cases (Case 5, 15, 17 and 18) were positive, whereas serum samples taken earlier in the disease course tested negative.

\section{Discussion}

Although viral detection is critical for disease surveillance and control, more clinically suspected cases of rabies are reported than laboratory-confirmed cases. In the absence of a history of exposure or typical symptoms, however, a diagnosis of rabies on clinical grounds alone may be difficult and often unreliable [8], and laboratory testing should be used to confirm the diagnosis [8].

Table 2 The detailed sampling data of the 18 confirmed cases by anti-mortem diagnosis (Red samples mean the positive results)

\begin{tabular}{|c|c|c|c|c|c|c|c|c|c|c|c|c|c|}
\hline \multirow{2}{*}{ Cases } & \multirow{2}{*}{ Samples } & \multirow{2}{*}{ Date of onset } & \multirow{2}{*}{ Date of death } & \multirow{2}{*}{ Date of collection } & \multirow{2}{*}{ After onset (days) } & \multirow{2}{*}{ Before death (days) } & & Saliva6 & 2012.3.8 & Unknown & 2012.3.28 10:00 AM & \multirow{2}{*}{20} & \multirow{2}{*}{ I } \\
\hline & & & & & & & & Saliva7 & 2012.3.8 & Unknown & 2012.3.28 8:00 PM & & \\
\hline Case 1 & Saliva & 2009.7 .4 & 2009.7 .11 & 2009.7 .6 & 2 & 5 & & Saliva8 & 2012.3.8 & Unknown & 2012.3.28 8:00 PM & 20 & I \\
\hline \multirow[t]{2}{*}{ Case 2} & Serum & 2010.3.8 & 2010.3.15 & 2010.3.13 & 5 & 2 & Case 11 & Saliva & 2012.3.27 & Unknown & 2012.3.29 & 2 & I \\
\hline & Saliva & 2010.3.8 & 2010.3.15 & 2010.3.13 & 5 & 2 & & Urine & 2012.3.27 & Unknown & 2012.3.29 & 2 & / \\
\hline \multirow[t]{3}{*}{ Case 3} & Serum & 2010.3.8 & 2010.3.19 & 2010.3.13 & 5 & 6 & & Serum & 2012.3.27 & Unknown & 2012.3.29 & 2 & / \\
\hline & Saliva & 2010.3.8 & 2010.3.19 & 2010.3.13 & 5 & 6 & Case 12 & Serum & 2012.7.12 & 2012.7.16 & 2012.7.15 & 3 & 1 \\
\hline & CSF & 2010.3 .8 & 2010.3.19 & 2010.3.13 & 5 & 6 & Case 13 & CSF & 2012.9.11 & 2012.9.19 & 2012.9.18 & 7 & 1 \\
\hline \multirow[t]{5}{*}{ Case 4} & Serum & 2010.8 .4 & 2010.8.19 & Unknown & I & I & & Saliva & 2012.9.11 & 2012.9.19 & 2012.9.18 & 7 & 1 \\
\hline & Saliva1 & 2010.8 .4 & 2010.8 .19 & 2010.8.13 & 9 & 6 & Case 14 & $\mathrm{CSF}$ & 2012.10.24 & Unknown & 2012.11.3 & 10 & I \\
\hline & Saliva2 & 2010.8 .4 & 2010.8.19 & 2010.8.14 & 10 & 5 & & Saliva1 & 2012.10.24 & Unknown & 2012.11.5 & 12 & I \\
\hline & Saliva3 & 2010.8 .4 & 2010.8.19 & 2010.8.15 & 11 & 4 & & Saliva2 & 2012.10.24 & Unknown & 2012.11.5 & 12 & I \\
\hline & Neck skin & 2010.8 .4 & 2010.8.19 & Unknown & I & I & & Saliva3 & 2012.10 .24 & Unknown & 2012.11.7 & 14 & I \\
\hline \multirow[t]{5}{*}{ Case 5} & $\mathrm{CSF}$ & 2010.8.27 & Unknown & 2010.9.2 & 6 & I & & Serum & 2012.10 .24 & Unknown & 2012.11.8 & 15 & I \\
\hline & Serum & 2010.8 .27 & Unknown & 2010.9.2 & 6 & / & Case 15 & Serum1 & 2012.12.17 & 2012.12.27 & 2012.12 .20 & 3 & 7 \\
\hline & $\mathrm{CSF}$ & 2010.8.27 & Unknown & 2010.9 .8 & 12 & I & & CSF & 2012.12.17 & 2012.12 .27 & 2012.12.21 & 4 & 6 \\
\hline & Saliva & 2010.8.27 & Unknown & 2010.9 .8 & 12 & I & & Saliva1 & 2012.12.17 & 2012.12.27 & 2012.12.21 & 4 & 6 \\
\hline & Serum & 2010.8 .27 & Unknown & 2010.9 .8 & 12 & I & & Saliva2 & 2012.12.17 & 2012.12 .27 & 2012.12 .23 & 6 & 4 \\
\hline Case 6 & Saliva & 2010.11.4 & 2009.11 .19 & 2009.11 .16 & 12 & 3 & & Saliva3 & 2012.12.17 & 2012.12 .27 & 2012.12 .24 & 7 & 3 \\
\hline \multirow[t]{3}{*}{ Case 7} & Serum & 2010.11.7 & Unknown & 2010.11.8 & 1 & I & & Serum2 & 2012.12 .17 & 2012.12 .27 & 2012.12 .24 & 7 & 3 \\
\hline & $\mathrm{CSF}$ & 2010.11.7 & Unknown & 2010.11 .8 & 1 & I & Case 16 & Saliva & 2012.12 .24 & 2012.12 .29 & 2012.12 .28 & 4 & 1 \\
\hline & Saliva & 2010.11.7 & Unknown & 2010.11.9 & 2 & I & Case 17 & Serum1 & 2015.3.26 & Unknown & 2015.3.26 & 0 & I \\
\hline \multirow[t]{2}{*}{ Case 8} & Serum & 2011.6.8 & 2011.6.15 & 2011.6.11 & 3 & 4 & & Serum2 & 2015.3.26 & Unknown & 2015.4.3 & 8 & / \\
\hline & Saliva & 2011.6.8 & 2011.6.15 & 2011.6.11 & 3 & 4 & Case 18 & Serum1 & 2016.4.30 & 2016.5.7 & Before 2016.5.6 & $<6$ & $>1$ \\
\hline \multirow[t]{3}{*}{ Case 9} & Serum & 2011.7.29 & 2011.8.5 & 2011.8.3 & 5 & 2 & & Serum2 & 2016.4.30 & 2016.5 .7 & 2016.5.7 6:30 PM & 7 & 0 \\
\hline & Serum & 2011.7.29 & 2011.8 .5 & 2011.8.4 & 6 & 1 & & Saliva1 & 2016.4.30 & 2016.5 .7 & 2016.5.6 2:00 AM & 6 & 1 \\
\hline & Serum & 2011.7.29 & 2011.8.5 & 2011.8 .5 & 7 & 0 & & Saliva2 & 2016.4.30 & 2016.5.7 & 2016.5.6 5:00 AM & 6 & 1 \\
\hline \multirow[t]{7}{*}{ Case 10} & Serum1 & 2012.3.8 & Unknown & 2012.3.16 & 8 & l & & Saliva3 & 2016.4.30 & 2016.5 .7 & 2016.5.6 8:00 AM & 6 & 1 \\
\hline & Serum2 & 2012.3.8 & Unknown & 2012.3.27 & 19 & I & & Saliva4 & 2016.4.30 & 2016.5 .7 & 2016.5.6 11:00 AM & 6 & 1 \\
\hline & Saliva1 & 2012.3.8 & Unknown & 2012.3.27 & 19 & I & & Saliva5 & 2016.4.30 & 2016.5 .7 & 2016.5.6 2:00 PM & 6 & 1 \\
\hline & Saliva2 & 2012.3.8 & Unknown & 2012.3.27 & 19 & I & & Saliva6 & 2016.4.30 & 2016.5 .7 & 2016.5.6 5:00 PM & 6 & 1 \\
\hline & Saliva3 & 2012.3.8 & Unknown & 2012.3.28 4:00 AM & 20 & I & & Saliva7 & 2016.4.30 & 2016.5 .7 & 2016.5.6 8:00 PM & 6 & 1 \\
\hline & Saliva4 & 2012.3.8 & Unknown & 2012.3.28 4:00 AM & 20 & I & & Saliva8 & 2016.4.30 & 2016.5 .7 & 2016.5.6 11:00 PM & 6 & 1 \\
\hline & Saliva5 & 2012.3 .8 & Unknown & 2012.3.28 10:00 AM & 20 & I & & Saliva9 & 2016.4.30 & 2016.5 .7 & 2016.5.7 6:30 PM & 7 & 0 \\
\hline
\end{tabular}

/ means not applicable 
The gold standard for confirmation of rabies is demonstration of viral antigen by FAT on brain tissue obtained post-mortem [8]. However, obtaining brain tissue after death remains a challenge and is rarely performed in China or many other countries $[11,16]$. Despite significant developments in laboratory techniques, antemortem diagnosis of human rabies is fraught with difficulties. Although a validated positive ante-mortem test result is indicative of rabies, a negative result does not necessarily rule out a diagnosis of rabies in all cases, which is a major limitation of ante-mortem testing [8]. A combination of several tests on multiple clinical samples, with serial sampling whenever feasible, is therefore recommended to increase the accuracy of ante-mortem diagnosis [11].

Nucleic acid amplification techniques, such as RTPCR, on saliva and CSF are increasingly being used for ante-mortem diagnosis of rabies. Our study shows that saliva RT-PCR provides the earliest and most sensitive positive diagnostic test (Tables 1 and 2). The typical characteristic of intermittent viral excretion in saliva samples is also evident in our study, which means that we strongly recommend collecting three or more serial daily saliva samples per patient.

The WHO and other experts recommend that serum samples should be used for anti-mortem diagnosis, but only used by measuring viral antibody [ 8 , 16 , 17]. Importantly, our study shows that serum or blood samples collected in the last 3 days of life can also be used to measure viral RNA. This means that serum samples, as well as other bodily fluids, such as saliva and CSF, can be used to detect viral RNA for anti-mortem diagnosis. We found that almost all the serum samples that tested positive were collected in the last 3 days of life (Table 2). Serum samples are easier to obtain than CSF samples, or even saliva samples in some situations at the end of life. Collection and analysis of serum in the late course of the disease will significantly increase the accuracy of anti-mortem diagnosis. Because of this, we have provided feasible sampling methods [18] and modified our "National Surveillance Project for Human Rabies". The new guidance for front-line staff in local CDCs, which adds the collection and testing of serum from the end period of survival, will improve our surveillance and laboratory diagnosis of human rabies. We also hope that our research will provide another option for other countries facing similar rabies problems.

This study was limited to the samples of human cases. More than 2/3 cases only were collected one specimen or a kind of tissue, and multiple samples from one case with detailed clinical information will better support our conclusions.

\section{Conclusions}

Serum or blood samples collected in the last 3 days of a patient's life can be used to measure viral RNA. We recommend that serum samples should be collected and used for anti-mortem diagnosis of rabies by measuring viral RNA since this will improve the positive test rate in human cases.

\section{Abbreviations}

CDCs: Centers for disease control and prevention; CSF: Cerebrospinal fluid; FAT: Florescent antibody Test; RT-PCR: Reverse transcription-polymerase chain reaction; WHO: World Health Organization

\section{Acknowledgements}

We'd like to thank the staffs in hospitals or local CDCs for collecting samples.

\section{Authors' contributions}

Conceived and designed the experiments: XYT WYZ. Performed the experiments: HL JJL SJD LC YF PCY SQL XXL. Analyzed the data: HL JJL XYT. Wrote the paper: HL JJL XYT. The author(s) read and approved the final manuscript.

\section{Funding}

This work was supported by the National Science and Technology Major Project (2017ZX10104001, 2018ZX10201002, 2018ZX10713002,

2018ZX10734404, 2018ZX10102001), the National Program on Key Research Project of China (2016YFD0500400), the National Key R\&D Program of China (2017YFC1200503), and the Science and Technology Project of Chinese Center for Disease Control and Prevention (JY18-2-12).

\section{Availability of data and materials}

The data were already showed in this study.

Ethics approval and consent to participate Not applicable.

\section{Consent for publication}

Not applicable.

\section{Competing interests}

The authors declare that they have no competing interests.

\section{Author details}

${ }^{1}$ Chinese Center for Disease Control and Prevention, Beijing, China. ${ }^{2}$ National Health Commission of the People's Republic of China, Key Laboratory of Biosafety, National Institute for Viral Disease Control and Prevention, Chinese Center for Disease Control and Prevention, 155 Changbai Road, Changping District, Beijing 102206, China. ${ }^{3}$ Shandong Center for Disease Control and Prevention, Jinan, Shandong, China. ${ }^{4}$ Hunan Center for Disease Control and Prevention, Changsha, Hunan, China. ${ }^{5}$ Yunnan Institute of Endemic Diseases Control and Prevention, Yunnan Provincial Key Laboratory for Zoonosis Control and Prevention, Dali, China.

Received: 16 January 2020 Accepted: 12 May 2020

Published online: 01 June 2020

\section{References}

1. WHO. Weekly epidemiological record. 2017, No 7(92):77-88.

2. Hampson K, Coudeville L, Lembo T, Sambo M, Kieffer A, Attlan M, et al. Estimating the global burden of endemic canine rabies. PLoS Negl Trop Dis. 2015;9(4):e0003709.

3. Rupprecht C, Kuzmin I, Meslin F. Lyssaviruses and rabies: current conundrums, concerns, contradictions and controversies. F1000Research. 2017;6:184.

4. Zhou H, Vong S, Liu K, Li Y, Mu D, Wang L, et al. Human rabies in China, 1960-2014: a descriptive epidemiological study. PLoS Negl Trop Dis. 2016; 10(8):e0004874. 
5. Liu JJ, Duo L, Tao XY, Zhu WY. Epidemiological characteristics of human rabies in China, 2017. Zhonghua Liu Xing Bing Xue Za Zhi. 2019;40(5):52630 (in Chinese).

6. Qian MB, Chen J, Bergquist R, Li ZJ, Li SZ, Xiao N, et al. Neglected tropical diseases in the People's Republic of China: progress towards elimination. Infect Dis Poverty. 2019;8(1):86

7. Tao XY, Li ML, Wang Q, Baima C, Hong M, Li W, et al. The reemergence of human rabies and emergence of an Indian subcontinent lineage in Tibet, China. PLoS Negl Trop Dis. 2019;13(1):e0007036.

8. Hemachudha T, Chokdamrongsuk J, Wacharasindhu DS, Abela-Ridder B, et al. WHO Expert Consultation on rabies, third report. Geneva: World health Organization; 2018

9. Amarasinghe GK, Arechiga Ceballos NG, Banyard AC, Basler CF, Bavari S, Bennett AJ, et al. Taxonomy of the order Mononegavirales: update 2018 Arch Virol. 2018:163(8):2283-94

10. Fooks AR, Banyard AC, Horton DL, Johnson N, McElhinney LM, Jackson AC. Current status of rabies and prospects for elimination. Lancet. 2014; 384(9951):1389-99.

11. Dacheux L, Wacharapluesadee S, Hemachudha T, Meslin FX, Buchy P, Reynes JM, et al. More accurate insight into the incidence of human rabies in developing countries through validated laboratory techniques. PLoS Negl Trop Dis. 2010:4(11):e765.

12. Tao XY, Tang Q, Li H, Mo ZJ, Zhang H, Wang DM, et al. Molecular epidemiology of rabies in southern People's Republic of China. Emerg Infect Dis. 2009;15(8):1192-8.

13. Tao XY, Guo ZY, Li H, Jiao WT, Shen XX, Zhu WY, et al. Rabies cases in the west of China have two distinct origins. PLoS Negl Trop Dis. 2015;9(10): e0004140.

14. Lang SL, Tao XY, Guo ZY, Tang Q, Li H, Yin CP, et al. Molecular characterization of viral $\mathrm{G}$ gene in emerging and re-emerging areas of rabies in China, 2007 to 2011. Virol Sin. 2012;27(3):194-203.

15. Tao XY, Li ML, Guo ZY, Yan JH, Zhu WY. Inner Mongolia: a potential portal for the spread of rabies to western China. Vector Borne Zoonotic Dis. 2019: 19(1):51-8.

16. Damodar T, Mani RS, Prathyusha PV. Utility of rabies neutralizing antibody detection in cerebrospinal fluid and serum for ante-mortem diagnosis of human rabies. PLoS Negl Trop Dis. 2019:13(1):e0007128.

17. Tiembre I, Dagnan S, Douba A, Adjogoua EV, Bourhy H, Dacheux L, et al. Epidemiologic monitoring of human rabies in an endemic canine rabies area in the Ivory Coast. Med Mal Infect. 2010;40(7):398-403.

18. Zhou H, Li Y, Chen RF, Tao XY, Yu PC, Cao SC, et al. Technical guideline for human rabies prevention and control (2016). Zhonghua Liu Xing Bing Xue Za Zhi. 2016:37(2):139-63 (in Chinese).

Ready to submit your research? Choose BMC and benefit from:

- fast, convenient online submission

- thorough peer review by experienced researchers in your field

- rapid publication on acceptance

- support for research data, including large and complex data types

- gold Open Access which fosters wider collaboration and increased citations

- maximum visibility for your research: over $100 \mathrm{M}$ website views per year

At $\mathrm{BMC}$, research is always in progress.

Learn more biomedcentral.com/submissions 